\title{
NAVIKA PIJENJA ALKOHOLA U ODNOSU NA NOĆNI RAD I SIGURNOST NA RADU
}

UDK 613.81:331.312.64]:331.45

PRIMLJENO: 5.5 .2015 .

PRIHVAĆENO: 4.4 .2016

\begin{abstract}
SAŽETAK: Ovim radom ispitivana je učestalost uzimanja alkohola kod radnika koji rade u različitim tipovima smjenskog rada u šest različitih radnih organizacija u Republici Hrvatskoj u kojima dominira smjenski rad. Ispitivanje je provedeno upitnikom Hrvatskog zavoda za zaštitu zdravlja i sigurnost na radu. Ciljevi rada bili su analiza povezanosti smjenskog rada i navike pijenja alkohola u odnosu na stupanj obrazovanja, privrednu granu, djelatnost radne organizacije ispitanika $i$ vrstu rada te percepciju vlastitog slobodnog vremena. U istraživanju je sudjelovalo 860 ispitanika, od kojih je 688 (80,0 \%) bilo muškog spola. Rezultati su pokazali statistički značajnu razliku u učestalosti uporabe alkohola između pojedinih radnih organizacija $(p<0,001)$ te razliku u konzumaciji između spolova (muškarci piju više, p<0,001). Najveći utjecaj smjenskog rada na naviku pijenja alkohola, ali i na ometanje slobodnog vremena zabilježen je kod radnika koji rade 7 do 15 noćnih smjena mjesečno. Od prediktorskih varijabli koje značajno povećavaju pijenje alkohola izdvajaju se: muški spol (muškarci imaju 4,33 puta veću šansu pijenja alkohola), utjecaj smjenskog rada na slobodno vrijeme (veći skor povećava šanse 1,32 puta) te mlađa dob (za svaku godinu života manje, šanse rastu 1/0,98=1,02 puta ili $2 \%$ ). Iz ovog modela može se utvrditi da je najvažnija intervencijska skupina u prevenciji pijenja alkohola na radnom mjestu skupina mlađih muškaraca u kojih smjenski rad značajno ometa njihovo slobodno vrijeme. Ovo istraživanje upućuje na ključnu preventivnu ulogu specijalista medicine rada u edukaciji radnika o štetnosti konzumacije alkohola te na osvješćivanje i radnika i poslodavca u težnji za nultom tolerancijom konzumiranja alkohola na radnim mjestima.
\end{abstract}

Ključne riječi: smjenski rad, alkohol, kvaliteta života

\section{UVOD}

Postoje mnoge definicije alkoholizma i alkoholičara, ali općeprihvaćene definicije još nema. Najčešće se primjenjuje definicija Svjetske zdravstvene organizacije (SZO) koja kaže da je alkoholičar bolesnik kod kojeg se zbog pre-

*Ana Zavalić, dr. med., (anazavalic@gmail.com), Dom zdravlja Zagrebačke županije - Zaprešić, Pavla Lončara 1, 10290 Zaprešić, prim. dr. sc. Marija Zavalić, Hrvatski zavod za zaštitu zdravlja i sigurnost na radu, Radoslava Cimermana 64 a, 10020 Zagreb, dr. sc. Milan Milošević, Sveučilište u Zagrebu, Medicinski fakultet, Škola narodnog zdravlja "Andrija Štampar", Katedra za zdravstvenu ekologiju i medicinu rada, Rockefellerova 4, 10000 Zagreb. komjerne i dugotrajne uporabe alkoholnih pića pojavljuju psihička i fizička ovisnost, zdravstveni problemi, obiteljski i društveni poremećaji (WHO, 2011.). Međunarodna klasifikacija bolesti, 10. izdanje (MKB-10) svrstava alkoholizam u poglavlje "Mentalni poremećaji i poremećaji ponašanja zbog upotrebe psihoaktivnih tvari" (F10.x). Prema Vladimiru Hudolinu alkoholizam je stil života, rizičan oblik življenja, posljedica ekoloških odnosa u društvu (Hudolin, 1982.). Osim kulturoloških razlika, prema većini objavljenih istraživanja na uzimanje alkoholnih pića utječe i ritam rada te rad u smjenama. Ove činjenice govore da je otkrivanje rizika za preko- 
mjerno konzumiranje alkohola jedan od bitnih čimbenika u prevenciji bolesti, ranijeg umirovljenja radnika osobito sada kada se životni vijek produljio. Prekomjerno uzimanje alkohola može naškoditi kako zdravlju ljudi tako i gospodarstvu pojedine zemlje. Postoji niz razloga za usmjeravanje pozornosti uporabi alkohola na radnom mjestu. To su prvenstveno problemi povezani s uporabom alkohola i zlostavljanjem, odnosno nasiljem na radu, povećani rizik od nesreća koje vode do ozljeda na radu, rizici povećane pojavnosti pojedinih bolesti, povećan broj neopravdanih izostanaka i bolovanja, a sve to dovodi do negativnih pojava na radu i povećanih troškova za poslodavce i radnike. Ovisno o državama, privrednim granama i zanimanjima, statistike upućuju na to da je u rasponu od 5 do $20 \%$ radnika alkoholičara ili su u opasnosti da to postanu (Webb i sur., 1994., Anderson i sur., 2006.).

Povećana potrošnja alkohola povezana je s povećanom stopom bolovanja (Norström i sur., 2006.). Različita razina uporabe alkohola uzrok je u razlikama u stopama incidencije i prevalencije pojedinih bolesti i preuranjene smrtnosti kod radnika u zemalja Europske unije (EU). Prema podacima raznih autora, približno $10 \%$ svih radnika konzumira redovito alkoholna pića svaki dan u tjednu (Zatonski i sur., 2008., Blomgren $i$ sur., 2004.). Prema podacima SZO-a konzumacija alkohola vodeći je svjetski čimbenik rizika smrtnosti među radno sposobnim muškarcima u dobi od 15 do 59 godina (WHO, 2011.).

\section{ISPITANICI I METODE}

\section{Ispitanici}

Istraživanje je provedeno u razdoblju od ožujka 2014. do srpnja 2014. godine. Uzorak čine radnici tiskare, zdravstveni radnici, radnici u proizvodnji kruha i pekarskih proizvoda, petrokemijske industrije i zaposleni u javnim vatrogasnim postrojbama koji su radili u prvoj smjeni i/ili u smjenama, uključujući i rad noću. $U$ istraživanju je sudjelovalo ukupno 860 radnika koji su bili na radnom mjestu u trenutku istraživanja.
Ispitanu skupinu činilo je 688 (80 \%) muškaraca i 168 žena (19,5\%), dok 4 ispitanika (0,5 \%) nije navelo spol.

\section{Metode}

Ovo istraživanje provedeno je uz pomoć upitnika Hrvatskog zavoda za zaštitu zdravlja i sigurnost na radu. Pitanja su strukturirana tako da postoji mogućnost izbora između 5 ponuđenih odgovora. Ispitanici su odgovorili na niz pitanja o tipu smjena, utjecaju smjenskog rada na njihov život i slobodno vrijeme te o svojim navikama pijenja alkohola. Statistička obrada provedena je u programu IBM SPSS 20, a u radu su primijenjene deskriptivna statistika, hi kvadrat test te binarna logistička regresija. Sve $p$ vrijednosti manje od 0,05 smatrane su značajnima.

Količina konzumiranog alkohola izražena je u čašama popijenog alkohola tjedno. Pod čašom alkohola smatra se: 0,33 I piva, 0,2 I vina, 0,033 I rakije, odnosno žestokog pića (=standardno piće).

Ispitani su radnici koji rade u smjenama. Ispitivanje u svakoj organizaciji bilo je provedeno u najmanje tri navrata te su obuhvaćeni svi smjenski radnici. Ove skupine radnika obuhvaćene su jer prema literaturi najčešće rade u tipu smjenskog rada, a uz to imaju najviše organizacijskih problema, te su najčešće izloženi stresu.

\section{REZULTATI}

Prosječna dob ispitanika bila je 43,30 godine, medijan 43 godine, a standardna devijacija 9,83. Najveći dio ispitanika, njih 703, imaju završenu srednju stručnu spremu, od toga 209 završeno trogodišnje, a 494 četverogodišnje srednjoškolsko obrazovanje. Njih 735 radi u noćnim smjenama, 286 do 7 noći mjesečno, 408 radnika radi 7 do 15 noći mjesečno, a 41 radnik radi više od 15 noćnih smjena mjesečno. Od ispitanih radnika koji rade u noćnim smjenama samo je njih 234 odnosno $28,4 \%$ navelo da im to ne ometa slobodno vrijeme, dok su ostali, njih 591, naveli da im rad u noćnim smjenama ometa slobodno vrijeme. 
Tablica 1. Opisna statistika u odnosu na promatrane kategorijske varijable

Table 1. Descriptive statistics in relation to tested category variables

\begin{tabular}{|c|c|c|c|}
\hline & & $\mathrm{N}$ & $\%$ \\
\hline \multirow{2}{*}{ Spol } & Muški & 688 & $80,4 \%$ \\
\hline & Ženski & 168 & $19,6 \%$ \\
\hline \multirow{4}{*}{ Dob: skupine } & $<=35$ godina & 217 & $25,3 \%$ \\
\hline & $35-45$ godina & 258 & $30,0 \%$ \\
\hline & 45-55 godina & 298 & $34,7 \%$ \\
\hline & $>55$ godina & 86 & $10,0 \%$ \\
\hline \multirow{5}{*}{ Stupanj obrazovanja } & završena/nezavršena OŠ & 37 & $4,4 \%$ \\
\hline & SSS - 3 godine & 209 & $24,7 \%$ \\
\hline & SSS - 4 godine & 494 & $58,5 \%$ \\
\hline & VŠS, VSS & 87 & $10,3 \%$ \\
\hline & poslijediplomski & 18 & $2,1 \%$ \\
\hline \multirow{4}{*}{ Noćne smjene mjesečno } & Ne radi noću & 125 & $14,5 \%$ \\
\hline & Radi do 7 dana & 286 & $33,3 \%$ \\
\hline & Radi 7 do 15 dana & 408 & $47,4 \%$ \\
\hline & Radi više od 15 dana & 41 & $4,8 \%$ \\
\hline \multirow{5}{*}{ Koliko smjenski rad ometa vaše slobodno vrijeme? } & Ne ometa & 234 & $28,4 \%$ \\
\hline & Ponešto ometa & 94 & $11,4 \%$ \\
\hline & Donekle ometa & 316 & $38,3 \%$ \\
\hline & Ometa & 61 & $7,4 \%$ \\
\hline & Značajno ometa & 120 & $14,5 \%$ \\
\hline \multirow{2}{*}{ Pijenje alkohola } & $\mathrm{Ne}$ & 555 & $67,0 \%$ \\
\hline & $\mathrm{Da}$ & 273 & $33,0 \%$ \\
\hline
\end{tabular}

Kao što je vidljivo iz Tablice 2, od ukupno 688 muškaraca, njih 243 u anketnom listu naznačilo je da konzumira barem jednu čašu alkohola tjedno, dok se kod žena njih 28 od ukupno 168 izjasnilo da pije barem 0,33 čaše alkohola tjedno. Prosječna dob ispitanika koji konzumiraju alkohol bila je 42,10, medijan 41,50 godina, a standardna devijacija 9,78. Nije bilo statistički značajne razlike u dobi između ispitanika koji konzumiraju alkohol i onih koji alkohol ne konzumiraju, iako su ispi- tanici koji ne konzumiraju alkohol bili neznatno stariji. Prosječni radni staž ispitanika bio je 18,75 godina, s rasponom od 1 do 35 godina. Što se tiče povezanosti stupnja obrazovanja i pijenja alkohola, najviše piju osobe s poslijediplomskim stupnjem obrazovanja. Od osoba koje piju alkohol, njih 214 navelo je da im smjenski rad ometa slobodno vrijeme, od toga 36 navodi da im smjenski rad ponešto ometa, 105 donekle ometa, 28 ometa te 45 značajno ometa. 
Tablica 2. Razlike u pojedinim kategorijskim varijablama u odnosu na naviku pijenja alkohola: $\mathrm{X}^{2}$ test

Table 2. Differences in individual category variables in relation to alcohol consumption habit: $\mathrm{X}^{2}$ test

\begin{tabular}{|c|c|c|c|c|c|}
\hline & & \multicolumn{4}{|c|}{ Pijenje alkohola } \\
\hline & & \multicolumn{2}{|c|}{$\mathrm{Ne}$} & \multicolumn{2}{|c|}{$\mathrm{Da}$} \\
\hline & & $\mathbf{N}$ & $\%$ & $\mathbf{N}$ & $\%$ \\
\hline \multirow{5}{*}{ Radna organizacija** } & Organizacija 1 & 230 & $74,2 \%$ & 80 & $25,8 \%$ \\
\hline & Organizacija 2 & 118 & $59,6 \%$ & 80 & $40,4 \%$ \\
\hline & Organizacija 3 & 56 & $65,9 \%$ & 29 & $34,1 \%$ \\
\hline & Organizacija 4 & 19 & $42,2 \%$ & 26 & $57,8 \%$ \\
\hline & Organizacija 5 & 132 & $69,5 \%$ & 58 & $30,5 \%$ \\
\hline \multirow{2}{*}{ Spol** } & Muški & 420 & $63,3 \%$ & 243 & $36,7 \%$ \\
\hline & Ženski & 134 & $82,7 \%$ & 28 & $17,3 \%$ \\
\hline \multirow{4}{*}{ Dob: skupine } & $<=35$ godina & 134 & $63,2 \%$ & 78 & $36,8 \%$ \\
\hline & $35-45$ godina & 155 & $63,3 \%$ & 90 & $36,7 \%$ \\
\hline & 45-55 godina & 208 & $72,7 \%$ & 78 & $27,3 \%$ \\
\hline & $>55$ godina & 57 & $67,9 \%$ & 27 & $32,1 \%$ \\
\hline \multirow{5}{*}{ Stupanj obrazovanja } & $\begin{array}{l}\text { završena/nezavrše- } \\
\text { na OŠ }\end{array}$ & 23 & $65,7 \%$ & 12 & $34,3 \%$ \\
\hline & SSS - 3 godine & 133 & $66,5 \%$ & 67 & $33,5 \%$ \\
\hline & SSS - 4 godine & 323 & $68,1 \%$ & 151 & $31,9 \%$ \\
\hline & VŠS, VSS & 56 & $64,4 \%$ & 31 & $35,6 \%$ \\
\hline & poslijediplomski & 10 & $55,6 \%$ & 8 & $44,4 \%$ \\
\hline \multirow{5}{*}{ Koliko smjenski rad ometa vaše slobodno vrijeme?** } & Ne ometa & 172 & $78,2 \%$ & 48 & $21,8 \%$ \\
\hline & Ponešto ometa & 53 & $59,6 \%$ & 36 & $40,4 \%$ \\
\hline & Donekle ometa & 202 & $65,8 \%$ & 105 & $34,2 \%$ \\
\hline & Ometa & 32 & $53,3 \%$ & 28 & $46,7 \%$ \\
\hline & Značajno ometa & 74 & $62,2 \%$ & 45 & $37,8 \%$ \\
\hline
\end{tabular}

${ }^{*} \mathrm{P}<0,05 ;{ }^{*} \mathrm{P}<0,001$

U Tablici 3 prikazane su razlike u pojedinim kategorijskim varijablama između kategorija noćnog smjenskog rada. Rezultati su pokazali da postoji statistički značajna razlika između pojedinih organizacija u broju noćnih smjena mjesečno. Kao što je vidljivo iz Tablice 3, radna organizacija 1, koja je dio petrokemijske industrije, ima $54,8 \%$ radnika koji rade od 7 do 15 noći mjesečno, u organizaciji 2 koju čine vatrogasci, također, većina (58,9\%) radi od 7 do 15 noći mjesečno. Radnici organizacije 3, koja obuhvaća pekarsku djelatnost, imaju 55,8 \% radnika koji rade u smjenama, ali ne rade noću ili nisu radili noću zadnjih mjesec dana i istovremeno 30,2 \% koji rade kontinuirano više od 15 noćnih smjena mjesečno. Radna organizacija 4 koja je dio tiskarske industrije ima 52 \% radnika koji rade do 7 noći mje- sečno i 44 \% koji rade od 7 do 15 noći mjesečno. Zadnju organizaciju čine zdravstveni djelatnici, od kojih 45,9\% radi do 7 noćnih smjena mjesečno, a njih 42,3\% radi od 7 do 15 noćnih smjena mjesečno. Veći je postotak muškaraca koji rade u noćnim smjenama, njih 87,4\% u odnosu na 77,4 \% žena. Ovisno o dobnim skupinama najviše noćnih smjena mjesečno odradi skupina radnika dobi niže od 35 godina, a najmanje noćnih smjena odradi starosna skupina od 45 do 55 godina života. Najviše noćnih smjena odrade radnici sa završenom srednjom stručnom spremom, a najmanje sa završenim poslijediplomskim studijem. Najveći utjecaj smjenskog rada na naviku pijenja alkohola, ali i na ometanje slobodnog vremena zabilježen je kod radnika koji rade 7 do 15 noćnih smjena mjesečno. 
Tablica 3. Razlike u pojedinim kategorijskim varijablama između kategorija noćnog smjenskog rada: $X^{2}$ test

Table 3. Differences in individual category variables among night work categories: $X^{2}$ test

\begin{tabular}{|c|c|c|c|c|c|c|c|c|c|}
\hline & & \multicolumn{8}{|c|}{ Noćne smjene mjesečno } \\
\hline & & \multicolumn{2}{|c|}{ Ne radi noću } & \multicolumn{2}{|c|}{ Radi do 7 noći } & \multicolumn{2}{|c|}{ Radi 7-15 noći } & \multicolumn{2}{|c|}{ Radi >15 noći } \\
\hline & & $\mathbf{N}$ & $\%$ & $\mathbf{N}$ & $\%$ & $\mathbf{N}$ & $\%$ & $\mathbf{N}$ & $\%$ \\
\hline \multirow{5}{*}{ Radna organizacija** } & Organizacija 1 & 27 & $8,4 \%$ & 115 & $35,6 \%$ & 177 & $54,8 \%$ & 4 & $1,2 \%$ \\
\hline & Organizacija 2 & 30 & $14,5 \%$ & 46 & $22,2 \%$ & 122 & $58,9 \%$ & 9 & $4,3 \%$ \\
\hline & Organizacija 3 & 48 & $55,8 \%$ & 10 & $11,6 \%$ & 2 & $2,3 \%$ & 26 & $30,2 \%$ \\
\hline & Organizacija 4 & 2 & $4,0 \%$ & 26 & $52,0 \%$ & 22 & $44,0 \%$ & 0 & $0,0 \%$ \\
\hline & Organizacija 5 & 18 & $9,3 \%$ & 89 & $45,9 \%$ & 82 & $42,3 \%$ & 5 & $2,6 \%$ \\
\hline \multirow{2}{*}{ Spol* } & Muški & 87 & $12,6 \%$ & 238 & $34,6 \%$ & 328 & $47,7 \%$ & 35 & $5,1 \%$ \\
\hline & Ženski & 38 & $22,6 \%$ & 46 & $27,4 \%$ & 76 & $45,2 \%$ & 8 & $4,8 \%$ \\
\hline \multirow{4}{*}{ Dob: skupine* } & $<=35$ godina & 19 & $8,8 \%$ & 80 & $36,9 \%$ & 100 & $46,1 \%$ & 18 & $8,3 \%$ \\
\hline & $35-45$ godina & 39 & $15,1 \%$ & 75 & $29,1 \%$ & 130 & $50,4 \%$ & 14 & $5,4 \%$ \\
\hline & 45-55 godina & 54 & $18,1 \%$ & 101 & $33,9 \%$ & 133 & $44,6 \%$ & 10 & $3,4 \%$ \\
\hline & $>55$ godina & 13 & $15,1 \%$ & 29 & $33,7 \%$ & 42 & $48,8 \%$ & 2 & $2,3 \%$ \\
\hline \multirow{5}{*}{ Stupanj obrazovanja** } & $\begin{array}{l}\text { završena/nezavrše- } \\
\text { na OŠ }\end{array}$ & 8 & $21,6 \%$ & 10 & $27,0 \%$ & 16 & $43,2 \%$ & 3 & $8,1 \%$ \\
\hline & SSS - 3 godine & 36 & $17,2 \%$ & 67 & $32,1 \%$ & 87 & $41,6 \%$ & 19 & $9,1 \%$ \\
\hline & SSS - 4 godine & 53 & $10,7 \%$ & 161 & $32,6 \%$ & 261 & $52,8 \%$ & 19 & $3,8 \%$ \\
\hline & VŠS, VSS & 21 & $24,1 \%$ & 38 & $43,7 \%$ & 26 & $29,9 \%$ & 2 & $2,3 \%$ \\
\hline & poslijediplomski & 4 & $22,2 \%$ & 7 & $38,9 \%$ & 7 & $38,9 \%$ & 0 & $0,0 \%$ \\
\hline \multirow{5}{*}{$\begin{array}{l}\text { Koliko smjenski rad ometa vaše } \\
\text { slobodno vrijeme?** }\end{array}$} & Ne ometa & 36 & $15,4 \%$ & 61 & $26,1 \%$ & 128 & $54,7 \%$ & 9 & $3,8 \%$ \\
\hline & Ponešto ometa & 4 & $4,3 \%$ & 45 & $47,9 \%$ & 42 & $44,7 \%$ & 3 & $3,2 \%$ \\
\hline & Donekle ometa & 39 & $12,3 \%$ & 102 & $32,3 \%$ & 161 & $50,9 \%$ & 14 & $4,4 \%$ \\
\hline & Ometa & 2 & $3,3 \%$ & 30 & $49,2 \%$ & 27 & $44,3 \%$ & 2 & $3,3 \%$ \\
\hline & Značajno ometa & 14 & $11,7 \%$ & 46 & $38,3 \%$ & 44 & $36,7 \%$ & 16 & $13,3 \%$ \\
\hline \multirow{2}{*}{ Pijenje alkohola } & $\mathrm{Ne}$ & 80 & $14,4 \%$ & 178 & $32,1 \%$ & 274 & $49,4 \%$ & 23 & $4,1 \%$ \\
\hline & $\mathrm{Da}$ & 40 & $14,7 \%$ & 101 & $37,0 \%$ & 114 & $41,8 \%$ & 18 & $6,6 \%$ \\
\hline
\end{tabular}

${ }^{*} \mathrm{P}<0,05 ; * * \mathrm{P}<0,001$

Tablica 4 prikazuje utjecaj pojedinih prediktorskih varijabli na pripadnost skupini koja pije alkohol. Regresijski model je statistički značajan $(\mathrm{P}<0,001)$ te ispravno klasificira $67 \%$ ispitanika. Od prediktorskih varijabli koje značajno povećavaju pijenje alkohola izdvajaju se: muški spol (muškarci imaju 4,33 puta veću šansu pijenja alkohola), utjecaj smjenskog rada na slobodno vrijeme (veći skor povećava šanse 1,32 puta) te mlađa dob (za svaku godinu života manje, šanse rastu $1 / 0,98=1,02$ puta ili $2 \%$ ). Iz ovog regresijskog modela može se utvrditi da je najvažnija intervencijska skupina u prevenciji pijenja alkohola na radnom mjestu skupina mlađih muškaraca u kojih smjenski rad značajno ometa njihovo slobodno vrijeme. 
Tablica 4. Predikcija navike pijenja alkohola u poslova sa smjenskim radom: binarna logistička regresija

Table 4. Prediction of alcohol consumption habit in jobs with shift work: binary logistic regression

\begin{tabular}{|c|c|c|c|c|c|c|c|c|}
\hline & \multirow{2}{*}{ B } & \multirow{2}{*}{ S.E. } & \multirow{2}{*}{ Wald } & \multirow{2}{*}{ df } & \multirow{2}{*}{ OR } & \multicolumn{2}{|c|}{$95 \% \mathrm{Cl}$} & \multirow{2}{*}{$\mathbf{P}$} \\
\hline & & & & & & Donji & Gornji & \\
\hline Muški spol & 1,46 & 0,26 & 31,91 & 1,00 & 4,33 & 2,60 & 7,19 & $<0,001$ \\
\hline Razina obrazovanja & 0,10 & 0,12 & 0,69 & 1,00 & 1,10 & 0,88 & 1,38 & 0,405 \\
\hline $\begin{array}{l}\text { Utjecaj smjenskog rada na } \\
\text { slobodno vrijeme }\end{array}$ & 0,28 & 0,06 & 20,74 & 1,00 & 1,32 & 1,17 & 1,49 & 0,001 \\
\hline Dob & $-0,02$ & 0,01 & 5,82 & 1,00 & 0,98 & 0,96 & 1,00 & 0,016 \\
\hline Broj noćnih smjena mjesečno & 0,00 & 0,02 & 0,01 & 1,00 & 1,00 & 0,97 & 1,03 & 0,931 \\
\hline
\end{tabular}

\section{RASPRAVA}

Svjetska zdravstvena organizacija objavila je 2014. godine podatke o konzumaciji alkohola među pojedinim zemljama članicama. Prema tim podacima, u Republici Hrvatskoj je 3,4\% alkoholičara, od toga 5,6 \% muškaraca i 1,4 \% žena (Global status report on alcohol and health, 2014.). Konzumacija alkohola povećava rizik od bolesti probavnog sustava, kardiovaskularnih bolesti, neuropsihijatrijskih poremećaja i nekih vrsta karcinoma (Rehm i sur., 2010.). Brojnim studijama dokazana je povezanost između uvjeta rada i razine konzumiranja alkoholnih pića ili čak prekomjernog pijenja (Siegrist i Rodel, 2006.). Tako su Nakamura i suradnici te Reeves i suradnici u svojim istraživanjima ustanovili da radnici koji rade u smjenama i oni koji rade prekovremeno češće piju alkohol svakodnevno ili barem jednom tjedno, a u ovoj skupini je i više alkoholičara nego među radnicima koji rade samo u prvoj smjeni (Nakamura i sur., 1997.). Naši rezultati pokazali su da radnici koji rade u prvoj i/ili prvoj i drugoj smjeni češće piju od radnika u noćnoj smjeni, ali da radnici koji piju, a rade u noćnoj smjeni, piju značajno veće količine alkohola od radnika koji rade danju $(p<0,05)$. Ti rezultati su u skladu s rezultatima Dorriana i suradnika iz 2012. godine. Kod radnika koji rade u smjenama češći su probavni problemi, češće su razdražljivi, a smanjuje se i njihova učinkovitost za obavljanje rutinskih zadataka što sve dovodi do češćih ozljeđivanja na radu. Kada se ovim poslovima pridruži i redovita konzumacija alkohola, problem se multiplicira. Rezultati ovog istraživanja nisu pokazali veću učestalost bolesti ni jednog od navedenih sustava. To se tumači time što su ispitanici relativno mladi i što se navedene bolesti nisu još uspjele manifestirati u toj mjeri da su se zbog njih javljali liječniku. Koliko je bitno istraživati pojavu konzumacije alkohola ovisno o uvjetima rada u svrhu predlaganja i provođenja preventivnih aktivnosti među radnicima na radnom mjestu govore i podaci da danas jedan od pet radnika u Europi redovito radi u smjenama, uključujući i noćnu smjenu (Harrington, 2001.). Alkohol obično služi kao pomoć pri usnivanju i spavanju. Uzimanje alkohola u početku je najčešće povezano s pomoći pri usnivanju. Gotovo 20 \% radnika koji rade u smjenama misli da ne bi zaspali bez alkohola i zato ga počinju uzimati (Soldatos i sur., 2005.). Rezultati ovog istraživanja nisu potvrdili podatke da radnici koji rade noću uzimaju alkohol kao pomoć pri spavanju, ali podatak da kada piju, piju veće količine alkohola, ostavljaju otvorenu mogućnost da alkohol konzumiraju upravo kao pomoć pri usnivanju. Podaci ovog našeg istraživanja u skladu su s podacima Roehrsa i Rotha (2001.) koji su utvrdili da radnici koji rade noću konzumiraju veće količine alkohola od onih koji rade danju. Autori pretpostavljaju da je uzrok tome povećana tolerancija na alkohol i sve veća potreba za uzimanjem veće količine alkohola kao sredstva za pomoć pri usnivanju kada se vrate iz noćne smjene. Postoje i studije prema kojima nema razlike u konzumaciji alkohola u odnosu na smjenski rad (Zinkiewicz i sur., 1999., Kivimäki, 2001., Van Amelsvoort i sur., 2004.). Istraživanje Lasfrageusa pokazalo je da radnici koji rade u smjenama piju manje od radnika koji rade samo prvu smjenu (Lasfargues i sur., 1996.). 
Naši rezultati pokazuju da radnici koji rade noću piju rjeđe, ali da oni koji piju, piju veće količine alkohola. Uzimanje alkohola povezano je i sa stručnom spremom - što je ona viša, manja je vjerojatnost da će radnici piti ili redovno biti alkoholizirani. Naše istraživanje pokazalo je da značajno više piju oni koji imaju percepciju lošeg općeg i psihičkog zdravlja, a to su baš radnici iz radnih organizacija s nižom i srednjom stručnom spremom. Utvrđeno je da potrošnja alkohola ovisi o dobi radnika. Najveće količine alkohola piju muškarci u dobi između 25 i 34 godina $(16,8$ \%) i žene u dobi od 16 do 24 godine (9,8\%); (Office for National Statistics Statistical Bulletin, 2012.). Od naših ispitanika prosječno najviše piju oni u dobi iznad 40 godina, a slijede oni od 39 i 29 godina. Od istraživanja provedenih u Republici $\mathrm{Hr}-$ vatskoj važno je ukazati na ono koje su 2012. godine proveli Ercegović i Milošević (2012.). Autori su utvrdili da postoji značajna negativna korelacija između CAGE zbroja i indeksa radne sposobnosti te značajnu negativnu povezanost ukupnog indeksa radne sposobnosti i vrijednosti popijenog alkohola izvan radnog vremena, tj. da više popijenog alkohola izvan radnog vremena uvjetuje manju radnu sposobnost. Za vrijeme posla najviše piju ispitanici dobne skupine od 45 do 55 godina, a izvan posla, ali za vrijeme radnog tjedna najviše pije dobna skupina iznad 55 godina. Najmlađa dobna skupina ( $<25$ godina) značajno više pije za vrijeme vikenda.

\section{ZAKLJUČAK}

$U$ istraživanju prikazanom u ovome radu ispitivana je povezanost razine obrazovanja i rada na određenom radnom mjestu i konzumacije alkohola, te utjecaj smjenskog rada na konzumaciju alkohola i percepciju zdravlja. Rezultati su pokazali statistički značajnu razliku u učestalosti konzumacije alkohola u odnosu na radnu organizaciju, spol te slobodno vrijeme radnika koji rade u smjenama.

Više ispitanika koji rade u dnevnim smjenama konzumira alkohol, ali kada piju, ispitanici koji rade noću piju značajno više alkohola od dnevnih radnika.
Rezultati rada upućuju na potrebu trajne edukacije radnika o štetnosti konzumiranja alkohola i na multidisciplinaran pristup ovom problemu.

\section{LITERATURA}

Anderson, P., Baumberg, B.: A/cohol in Europe. Institute of Alcohol Studies, London, 2006., dostupno na: http://ec. europa. eu/health/ ph_ determinants/life_style/alcohol/documents/alcohol_europe. pdf., pristupljeno: 22.12. 2014.

Blomgren, J. i sur.: The effects of regional characteristics on alcohol-related mortality - a registerbased multilevel analysis of 1.1 million men. Social Science and Medicine, 58, $2004 .$, 12, 2523-2535.

Dorrian, J., Skinner, N.: Alcohol... Compared with Dayworkers', Chronobiology International, 29, 2012., 5, 610-618.

Ercegović, E., Milošević, M.: Prekomjerno pijenje alkohola i radna sposobnost u muškaraca. Sigurnost, 54, 2012., 2, $127-135$.

Global status report on alcohol and health, 2014., dostupno na: www.who.int/substance_ abuse/publications/global_alcohol_report/en/, pristupljeno: 4.1.2015.

Hudolin, V.: Ovisnost o alkoholu: priručnik za liječnika opće medicine, Školska knjiga, Zagreb, 1982.

Jenkins, R., Harvey, S., Butler, T., Thomas, RL.: A six year longitudinal study of the occupational consequences of drinking over 'safe limits' of alcohol. Br J Ind Med., 49, 1992., 5, 369-374.

Lasfargue, G., Vol, S., Cacés, ET., Le Clésiau, H., Lecomte, P., Tichet, J.: Relations among night work, dietary habits, biological measures, and health status. Int J Behav Med., 3, 1996., 2, 123-134.

Letak o ovisnosti alkoholu, dostupno na: http://www.unizd.hr/portals/27/pdf/letak_ovisnost.pdf, pristupljeno: 4.1.2015. 
Nakamura, K., Shimai, S., Kikuchi, S., Tominaga, K., Takahashi, H., Tanaka, M., Nakano, S., Motohashi, Y., Nakadaira, H. and Yamamoto, M.: Shift work and risk factors for coronary heart disease in Japanese blue collar workers: serum lipids and anthropometric characteristics. Occupational Medicine, 47, 1997., 3, 142146.

Norstrom, T.: Per capita alcohol consumption and sickness absence. Addiction, 110, 2006., 10, 1421-1427.

Ohira, T., Tanigawa, T., Iso, H. i sur.: Effects of shift work on 24-hour ambulatory blood pressure and its variability among Japanese workers. Scand J Work Environ Health, 26, 2000., 3, 421-426.

Ragland, DR., Greiner, BA., Krause, N., Holman, BL., Fisher, JM.: Occupational and nonoccupational correlates of alcohol consumption in urban transit operators. Prev Med., 24, 1995. 6, 634-645.

Reeves, S.L., Newling Ward, E. and Gissane, C.: The effect of shift work on food intake and eating habits. Nutrition and Food Science, 34, 2004., 5, 216 221. Prema de Assis i suradnicima (de Assis, M.A.A., Kupek, E., Nahas, M.V. and Bellisle, F. 2003a. Food intake and circadian rhythms in shift workers with a high workload. Appetite, 40(2):175 183.)

Rehm, J. i sur.: Global burden of disease and injury and economic cost attributable to alcohol use and alcohol use disorders. Lancet, 373, 2009, 9682, 2223-2233.

Rehm, J. i sur.: The relation between different dimensions of alcohol consumption and burden of disease: an overview. Addiction, 105, 2010., 5, 817-843.

Roehrs, T., Roth, T.: Sleep, sleepiness, sleep disorders and alcohol use and abuse. Sleep. Med Rev ... Psychophysiology, 38, 2001., 6, 979-987.
Siegrist, J., Rödel, A.: Work stress and health risk behavior. Scand J Work Environ Health, 32, 2006., 6, 473-81.

Soldatos, C. R., Allaert, F. A., Ohta, T. and Dikeos, D. G.: How do individuals sleep around the world? Results from a single-day survey in ten countries. Sleep Med., 6, 2005, 1, 5-13.

Uživanje alkohola i droga na radnom mjestu - Eurofound, dostupno na: eurofound.europa.eu/sites/.../ef.../EF12231HR.pdf, pristupljeno: 29.12.2014.

Van Amelsvoort, L.G., Schouten, E.G. and Kok, F.J.: Impact of one year of shift work on cardiovascular disease risk factors. Journal of Occupational and Environmental Medicine/American College of Occupational and Environmental Medicine, 46, 2004., 7, 699706.

Varjačić, T., Braš, M., Brajković, L., Domokuš, A., Đorđević, V.: Stres i posljedice stresa liječnika onkologa. Soc. psihijat., 41, 2013., 2, 118-122.

Webb, GR., Redman, S., Hennrikus, DJ., Kelman, GR., Gibberd, RW., Sanson-Fisher, RW.: The relationships between high-risk and problem drinking and the occurrence of work injuries and related absences. J Stud Alcohol, 55, 1994., 4, 434-446.

World Health Organization. Global Status Report on Alcohol and Health, 2011.

Zatonski, W.: Closing the health gap in European Union. Maria-Sklodowska-Curie Memorial Cancer Center and Institute of Oncology, Warsaw, 2008., dostupno na: http://www.hem. home.pl/index.php? idm=87,139\&cmd=1, pristupljeno: 30.12. 2014.

Zinkiewicz, L., Davey, J., Obst, P., Sheehan, M.: Tracking it down: predictors of risky drinking in an Australian railway. J Alcohol Drug Educ, 44, 1999., 2, 44-59. 


\section{THE HABIT OF ALCOHOL CONSUMPTION IN RELATION TO NIGHT WORK AND SAFETY AT WORK}

SUMMARY: The aim of the study was to show whether there is a link between alcohol consumption, level of education, shift work and the perception of the quality of life.

This study examined the prevalence of alcohol consumption among employees working in different types of shift work in six different organizations in the Republic of Croatia. The survey was conducted with a questionnaire designed by the Croatian Institute for Health Protection and Safety at Work. The study aimed to estimate the use of alcohol in relation to the level of education, economic sector, business and labour organization and alcohol consumption in relation to the workers' perception of their own free time.

The study included 860 subjects, of whom 688 (80.0\%) were male. The results showed a statistically significant difference in the frequency of alcohol use among individual work organizations ( $p<0.001$ ) and a difference in consumption between the sexes (men drink more alcohol, $p<0.001$ ). The biggest impact of shift work on the habit of alcohol drinking and in disturbance of free time was found in the group working 7 to 15 night shifts per month. This study points to the crucial role of occupational medicine in worker education regarding the harmful effects of alcohol consumption and raising awareness of workers and employers as to the importance of zero tolerance of alcohol consumption in the workplace.

Key words: alcohol, workplace, shift work, quality of life

Original scientific paper Received: 2015-05-05

Accepted: 2016-04-04 